\title{
全身の骨病変を伴った過長茎状突起症例
}

\author{
鈴木 慎二1) 庄司 和彦1) ・ 高北 晋一2) ・池上 聰1) \\ 河田 恭孝3) • 丸毛みゆき1) ・ 岸本 曜1) ・ 児嶋 剛(1)
}

\section{Elongated Styloid Process with Systematic Ossifying Changes}

\author{
Shinji Suzuki, Kazuhiko Shoji, Satoshi Ikegami, \\ Miyuki Marumo, Yo Kishimoto and Tsuyoshi Kojima \\ (Tenri Hospital) \\ Shinichi Takagita \\ (Kyoto National Hospital) \\ Yasutaka Kawata \\ (Shizuoka General Hospital)
}

We report a 44-year-old man with elongated styloid process and greater cornu of hyoid bone. The chief complaint was right neck pain on turning his head and the symptom had continued for one year. CT scan was useful for the diagnosis of both lesions. Surgical shortening of elongated styloid process and greater cornu of the hyoid bone was performed using the transcervical approach, and his symptom disappeared. The transcervical approach had the advantage of wide visualization and we could perform the surgical therapy safely.

The case involved hypertrophy of the tibial tuberosity and block vertebra (Th7-8). These findings suggest that the elongated styloid process and hyoid bone were part of systematic ossifying changes of the osteo-chondro tissue.

Key words : elongated styloid process, hypertrophy of tibial tuberosity, block vertebra

\section{はじめに}

過長茎状突起が頸部痛を引き起こすことはよく知られ ている. しかし，頻度は多くないため日常診療において は見落とされやすく，不運にもノイローゼとして精神科 や心療内科で治療された例も報告されており ${ }^{1)}$, 忘れて はならない疾患である. 最近当科で過長舌骨を伴った過 長茎状突起症例を経験し, 治療として頸部外切開のアプ ローチによる手術を行ったが，この症例は脛骨粗面の肥
大と胸椎の癒合椎もみられ, 本疾患との関連が示唆され たため以下に報告する。

\section{症例}

症 例：44 歳, 男性.

主 訴：右顎下部から耳後部痛.

既往歴: 高脂血症（内服中）.

現病歴: 平成 13 年秋頃にあくびをしたり首を動かした

1）天理よろづ相談所病院耳鼻咽喉科

2) 国立京都病院耳鼻咽喉科

3）静岡県立総合病院耳鼻咽喉科 


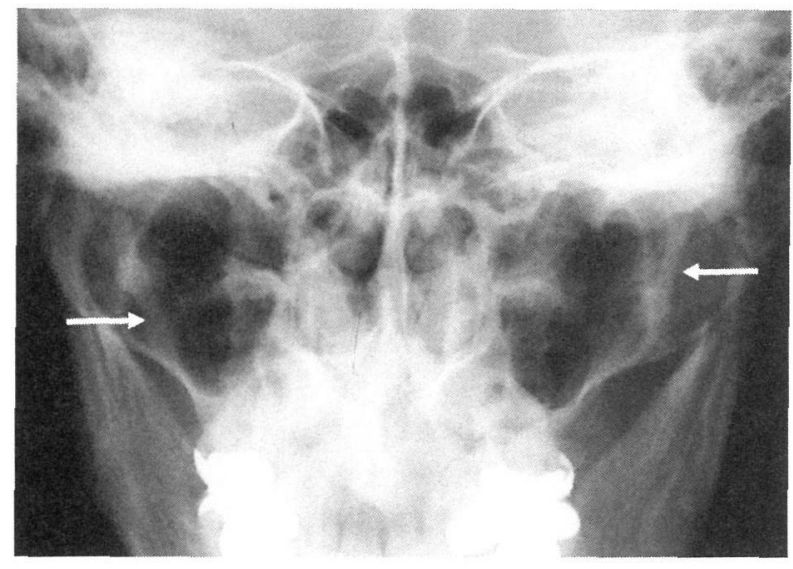

図 1 頭部単純 X 線写真正面像 茎状突起を矢印で示す.

りした時に, 右の顎下部から耳後部にかけての痛みが出 現したため, 当院口腔外科および整形外科を受診したが, 特に異常を指摘されなかった。その後, 徐々に痛みが増 強するため, 平成 14 年 10 月 28 日に神経内科を受診し た. 脳 CT で異常がなかったため, 翌日当科紹介受診と なった。

局所所見：扁桃炎や咽頭炎はなく, 扁桃窩を触診する 々弾性のある索状硬結物を触れ両側々も圧痛があった。 しかし頸部の触診では自覚症状のある右側にのみ痛が あった。

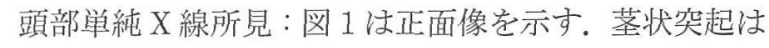
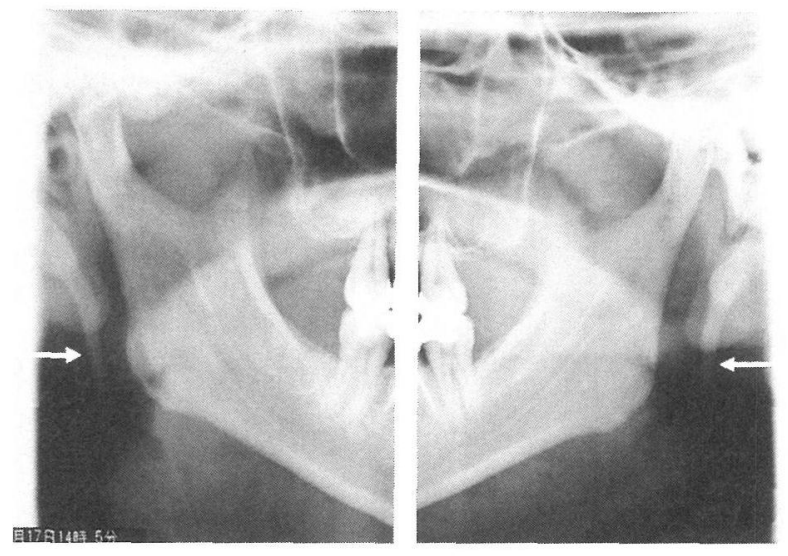

図 2 蒾槽骨パノラマX線写真 茥状突起を矢卵で示す。

描出されているが，顔面骨との重なりのために辺縁が はっきりしない.

歯槽骨パノラマ X 線所見: 単純 X 線写真と比べて, 茥 状告起の辺縁がよく描出され，通常より長くなっている のが確認された (図 2)。この歯槽骨パノラマX線写真か ら推定した茥状突起の長さは両側とも約 $4 \mathrm{~cm}$ であった.

頸部 CT 所見：口盍扁桃レベルの水平断（図3a）では, 頸動脈の前内方に茎状突起が描出されている。舌骨レベ ル（図 3 b）では舌骨大角部は通常より長くなっている. 以上の結果から過長茥状突起および過長舌骨との診断に 至った。

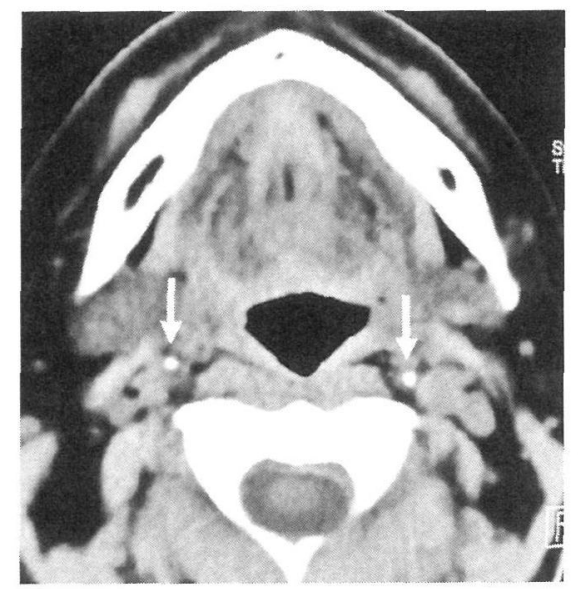

a

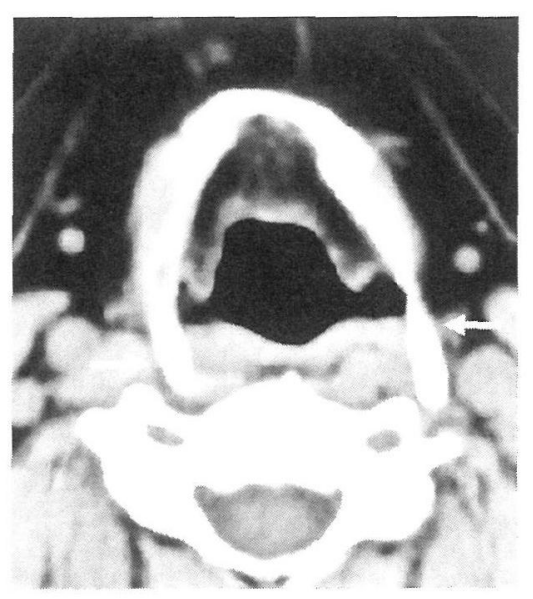

b

図 3 頸部 CT 所見（造影なし・水平断） 矢印は口蓋扁桃レベル（a）ではで茎状突起を，喑レベル（b）では号骨大角部を示す. 


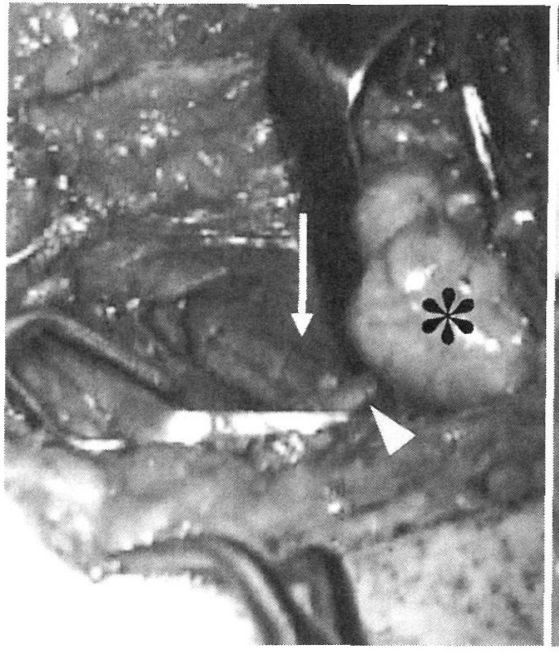

a

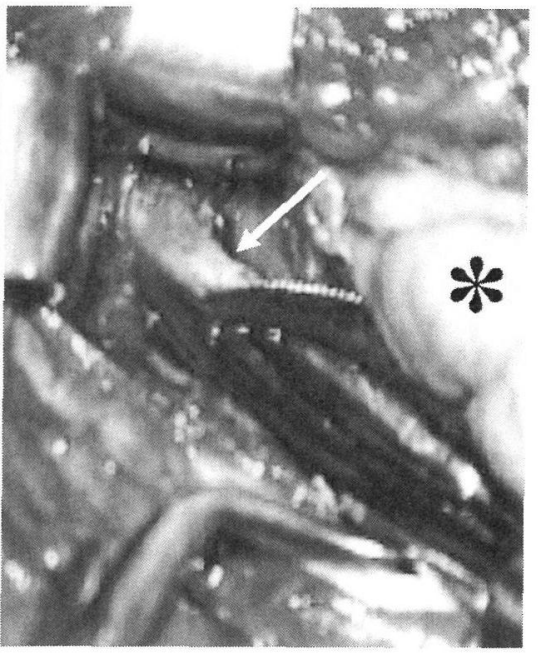

b

図 4 術中所見

（a）（b）とも上が頭側，下が尾側である。*は顎下腺，矢頭は顔面動脈を示す，矢印は（a）では茎状突起先端を，(b) では同 基部を示す.

経過：本人は手術治療を希望し, 茎状突起と舌骨の一 部を切除するために, 頸部外切開によるアプローチを選 択した。過長荃状突起および過長舌骨以外に原因がある こともありうるため，その場合は手術してもよくならな いことを本人に説明して了解を得た上で, 平成 15 年 2 月 19 日に全身麻酔下に手術を行った。

術中所見：顎下腺摘出術と同じレベルでそれより少し 長い皮切 $($ 約 $10 \mathrm{~cm})$ を入れ，まず顎下腺と顎二腹筋後腹 の間からアプローチした。 顔面動脈を確認し, その梁部 に茎状突起先端を触れた（図 4 a)，その先端に付着する 筋組織（茎突咽頭筋と荠突舌筋）を切開剥離して茎突舌 骨筋を切断した後，茎状突起の末梢側引き出し，荎状 突起全体を明視下においた。図4 b のように茎状突起の基 部の方は筋が付着しておらず疎な結合組織がついている のみであり, 周囲組織から容易に剥離できた。最後に上 向きスタンツェを用いてなるべく基部に近いところで切 除した。

次に, 舌骨の大角部に付着している筋組織を切開剥離 して大角部を引き出し，この大角部のほとんどを骨剪刀 で切除した。術中の出血量は $10 \mathrm{ml}$ と少量であった。

摘出標本: 図 5 に切除した $3 \mathrm{~cm}$ を超える舌骨大角部と $3 \mathrm{~cm}$ 弱の菱状突起を示す。

術後経過: 術後は顔面神経下顎縁枝の麻痺はみられず, 術前に絁まされていた痛みは消失した。また，術後半年

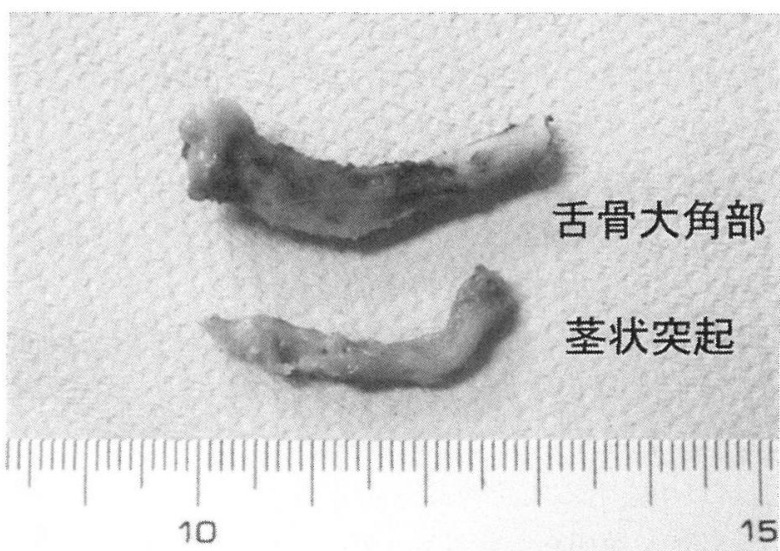

図 5 摘出標本

経った現在まで症状の再発はみられていない。

複数部位において骨の巽常が存在したため，全身骨の 検索を行ったところ，ほかに脛骨粗面の肥大（図6a）と 第 7-8 胸椎の癒合椎（図 6 b）があった. 脛骨粗面の肥大 による関節痛のため以前に局所注射療法を受けたことが あり，瘉合椎に関しては腰痛の精査時にたまたま発見さ れたとのことであった。このことから本症例の過長茎状 突起拉よび過長舌骨は，全身の骨軟骨組織および勒帯組 織における異常骨化に伴った病態の一部である可能性が 示唆された。 


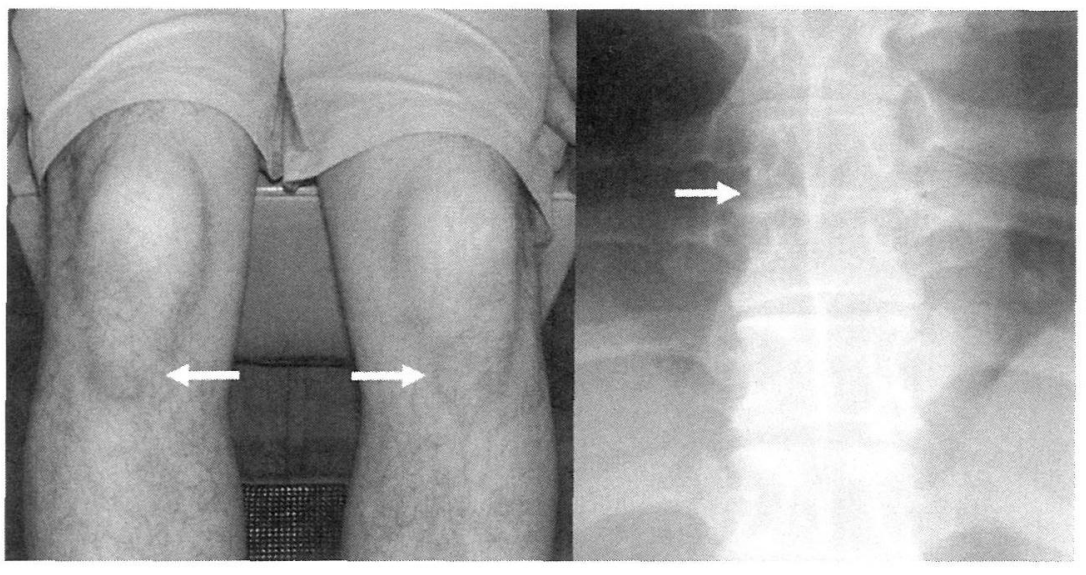

a

b

図 6 随伴する骨軟骨病変

（a）は肥大した脛骨粗面を，（b）は第 7-8胸椎の癒合椎を矢印で示す.

考察

過長茎状突起は思春期以降の骨化が進行して生じると いわれており，20 代から高齢者に至るまであらゆる年齢 層にみられる。過長舌骨については過去の報告も少なく 発生機序も不明だが, 他の頸部疾患のために撮影したCT 写真を注意深く観察すると意外に頻度は多いともいわれ ている。本症例の過長茎状突起, 過長舌骨とも stylohyoid chainの骨化 ${ }^{2)}$ による一連の変化と考えるられる.

茎状突起の長さについては, 本邦人の平均は約 $1.75 \mathrm{~cm}$ で，欧米人の平均は $2.5 \mathrm{~cm}$ といわれている3 ${ }^{3)}$. 本邦人に おいて $3.5 \mathrm{~cm}$ 以上で口蓋扁桃に達する可能性があり, $5 \mathrm{~cm}$ 以上をもって舌骨に達する可能性があるといわれ

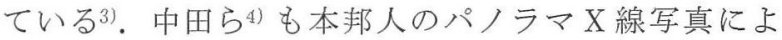
る計測で $2.5 \mathrm{~cm}$ を超える症例は $15.5 \%$ に達すると述べ, Correll ら ${ }^{5)}$ は, 欧米人に関して $3 \mathrm{~cm}$ を超える症例は 18.2 \%に達するが，そのらち症状を呈するのはきわめてわず かであったと述心゙ている，過長茎状突起の基準ははっき りと定められているわけではないが，本邦の文献上では $3 \mathrm{~cm}$ 以上で過長茎状突起と分類している例が多い.

過長茥状突起に伴ら症状としては, 頸部痛, 咽頭痛, 耳痛，咽喉頭異常感や肩こりなどが代表的である。痛み の原因として, 舌咽神経, 迷走神経や三叉神経などの頸 部を走行する神経への物理的刺激が考えられ，特に頸部 揄転時に痛みが増強することが多い。さらに，舌咽神経 は耳管や鼓室内に神経叢を形成しているため耳痛や耳鳴 りなどの耳症状も引き起こす。巵こりは茎状突起により
刺激された神経に吻合する交感神経が影響を受け，局所 の自律神経失調として疼痛および循環障害が生じた結果 であるといわれている677)、荠状突起の長さ以外の形態異 常が症状に及ぼす影響として，内方への屈曲が強いほど 症状も強い傾向にあるといわれており8)，これは内側を 走行する舌咽神経が機械的刺激を受ける可能性が高くな るためと考えられている。本症例においても茥状突起の 末梢側は途中で内方に屈曲していた。

過長舌骨に伴う症状としては咽喉頭晎常感が主な症状 であるが，なかには頸部捻転時の頸部痛，甲状軟骨や頸 椎突起との擦過により生じるクリック音910)などがある。 痛みの原因としては，長くなった舌骨大角部による咽頭 周囲の神経, 舌咽神経頸動脈洞枝や頸動脈洞周囲の交感 神経叢への機械的刺激が考えられている3 ${ }^{3)}$. 過長舌骨に よる疼痛は典型的な症状ではないため, 前述のように本 症例では過長茥状突起による痛みの可能性が高いと思わ れたが，術後に咽喉頭異常感や痛みが残る可能性も考え られたため, 長くなっている舌骨大角部も同時に切除し た。

治療としては, 筋弛緩剤, 鎮痛剤や安定剤などの保存 的治療が有効なことも多く，まず試みるべきであると思 われる。保存的治療で抵抗性の場合は手術的治療を考慮 すべきである。本症例では 1 年間にわたり疼痛に悩まさ れており，患者が手術を希望したため保存的治療として 術前に鎮痛剤を使用したのみであった。外科的切除のア プローチとしては口内法と頸部外切開法があるが，特に 
過長茎状突起に対しては過去の文献をみても口内法で治 療されている例8111) 13) が多い. 口内法の長所として, (1)頸部に術創が残らない，(2)短い距離で茎状突起まで到 達できる点が挙げられる，その反面短所として，(1)口腔 内の術創から深頸部感染をきたす可能性がある，(2)視野 が狭く大血管周囲を操作する際には危険が伴う，(3)扁桃 摘出を行う場合は術後の疼痛が強い，(4)茎状突起が長く 太い場合は口内から摘出するのは難しい点がある．口内 法による合併症として, 皮下気腫 ${ }^{14)}$ や内頸動脈血栓症 ${ }^{15)}$ の報告も過去にみられる．しかし，Strauss ら ${ }^{14)}$ は最終 的には症例に応じてアプローチ法を選択すればよいと述 べている. 過長舌骨に対しては口内法による切除は非常 に困難で，過去の文献では頸部外切開で治療を行ってい る例910) が多い，本症例では過長舌骨む伴っていたため 頸部外切開で手術を行ったが，視野良好で術中の出血量 も少なく，安全に行うことができた。もちろん年齢や性 別により，特に若年女性などの外切開に抵抗を感じる例 では，本症例のような場合でも口内法を考慮しなければ ならないときもあると思われる.

本症例では脛骨粗面の肥大や癒合椎を伴っていたが, 茎状突起と舌骨も含めて骨の異常がみられた部分の病態 として，軟骨あるいは勒帯の骨化が進行した結果と考え られる。通常，茎状突起の基部と先端は軟骨が存在し菱 状突起の可動性があれば発症しないが，基部と先端が固 定されて可動性がなくなると周囲の神経への刺激が生じ て痛みなどの症状が出現するとのことである ${ }^{3)}$ ．過去に stylohyoid chain の骨化例において頸椎前縦勒帯の異常骨 化を伴った報告16) はあるが，それ以外に全身の骨病変を 伴った例についてはほとんど報告されていない.しかし， 本症例で特に遺伝性は認めなかった。実際，全身の他の 部位に異常があったとしても，部位によってそれぞれ骨 化が進行する時期が異なるため症状出現にズレがあった り，骨化が進行しても無症状であることもあるために， 発見あるいは指摘されにくいのではないかと思われた。

\section{まとめ}

1）過長舌骨を伴う過長茎状突起の 1 例を報告した.

2）頸部外切開による切除手術は, 視野良好で安全な術 式である。

3）脛骨粗面の肥大と癒合椎を伴っており,骨軟骨組織 および勒帯組織における異常骨化に伴った病態の一部で ある可能性が示唆された。
本論文の要旨は, 日本口腔・咽頭科学会第 16 回学術講演会 （2003 年 9 月 13 日，東京都）に扔いて口演した.

\section{参考文献}

1）添田 弘，水川 保，木村 睛，他：精神異常を思わせる 訴えを伴った茥状突起過長症一訴えの心理学的考察一. 耳 展 $12: 23 \sim 25 ， 1969$.

2) Krennmair $G$ and Piehslinger $E$ : Variants of ossification in the stylohyoid chain. Cranio $21: 31 \sim 37,2003$.

3）奈良四郎：異常茎状突起の臨床的X線学的研究. 日耳鼻 61 : $1295 \sim 1301 ， 1958$

4）中田正之, 西尾順太郎, 綿谷和也, 他 : 茎状突起の発育に 関する X 線学的検討。 日口外誌 $33: 2224 \sim 2229 ， 1987$.

5) Correll RW, Jensen JL, Taylor JB, et al. : Mineralization of the stylohyoid-stylomandibular ligament complex; a radiographic incidence study. Oral Surg Oral Med Oral Pathol $48: 286 \sim$ 291, 1979 .

6）田中 明：異常茎状突起症に関する研究. 日耳鼻 $63: 2371$ $\sim 2391,1960$.

7) Eagle WW : Symptomatic elongated styloid process. Arch Otolaryngol $49: 490 \sim 503,1949$.

8）田中和成, 小澤博史, 北嶋和智 : 過長菱状突起症の 4 例. 耳 鼻臨床 $90 ： 1255 \sim 1261,1997$.

9）本多德行，斎藤 等，山田武千代，他：舌骨過長症の一治 験例. 耳鼻臨床 補 $63: 154 \sim 157,1993$.

10）勝見直樹，岩武博也，富澤秀雄，他：舌骨症候群例。耳鼻 臨床 $93: 223 \sim 228,2000$.

11）朝隈真一郎, 柴田浩一, 未田卓也: 過長茎状突起症. 臨床 と研究 $52 ： 1120 \sim 1124,1975$

12）古市一郎，八幡則子, 馬場廣太郎, 他 : 咽喉頭異常感症の 局所的要因. 耳展 $21: 295 \sim 301,1978$.

13）鶴田至宏, 佐藤武男, 宮原 裕, 他: 咽頭異常感を訴えた 過長茎状突起症の 4 症例. 耳鼻臨床 78:2783 2791, 1985 .

14) Strauss $M, Z$ Zohar $Y$ and Laurian $N$ : Elongated styloid process syndrome; intraoral versus external approach for styloid surgery. Laryngoscope $95: 976 \sim 979,1985$.

15) Riediger $D$ and Ehrenfeld $M$ : Pathogenesis and clinical manifestation of the styloid syndrome. Dtsch Zahnarztl Z 44:968 970, 1989.

16) Guo B, Jaovisidha S, Sartoris DJ, et al. : Correlation between ossification of the stylohyoid ligament and osteophytes of the cervical spine. J Rheumatol $24: 1575 \sim 1581,1997$.

原稿受付：平成 15 年 9 月 29 日 原稿採択：平成15年12月 24 日 別刷請求先 : 鈴木慎二

厂632-8552 天理市三島町 200

天理よろづ相談所病院耳鼻咽喉科 